| Research Article / Araştırma Makalesi|

\title{
Conversation Analytic Examination of Inquiry-Based Science Classrooms
}

\section{Sorgulama Dayalı Fen Sınıflarının Etkileşimsel Çözümlemesi ${ }^{1}$}

\section{Gökhan Kaya², Gültekin Çakmakçı ${ }^{3}$}

\section{Keywords \\ 1. conversation analysis \\ 2. classroom interaction \\ 3. inquiry-based science education \\ 4. language of science \\ Anahtar Kelimeler \\ 1. konuşma \\ çözümlemesi \\ 2. sınıf etkileşimi \\ 3. sorgulamaya dayalı \\ fen eğitimi \\ 4. bilimin dili}

Received/Başvuru Tarihi

21.05.2021

Accepted / Kabul Tarihi

17.08.2021

\section{Abstract}

Purpose: Recent policy and reform documents in education have promoted inquiry-based learning, which is seen as an effective way of teaching science. However, there are few studies evaluating the teacher-student interactional structure of inquirybased science (IBS) classes. Although the class is a social place, where learners are in the process of social interaction as a coconstruction process, this lack of research limits our understanding of the nature of interaction in IBS classes. The lack of understanding of this interactive structure causes teachers to provide the desired answers to the theoretical questions that are asked outside the classroom, but the results in the classroom are not at the desired level.

Design/Methodology/Approach: On this basis, this study examines IBS classroom interaction by the micro-analytic conversation analysis (CA) method to reveal the interactional phenomena within the classroom. The study was conducted with two science teachers and their 56 fifth-grade students. A database of 12 hours of IBS interactions was examined line-by-line and turn-byturn using $C A$.

Findings: Findings show that there are interactionally different phases in the practice of IBS classes and that teacher-student interactions also change according to context. These stages were named (1) initiating the inquiry, (2) focusing on the investigation, and (3) sharing understanding. Within these different phases of a science lesson, the pedagogical aims of the teachers and the interactive tools are found to differ.

Highlights: This has important implications for the study of the subjects and the class, which are dealt with in depth in terms of science education under a different conceptual framework. In addition, this study presents a contribution to CA research in terms of examining the interactional characteristics of science classes.

Öz

Çalışmanın amacı: Eğitimdeki son politika ve reform belgeleri, fen öğretiminin etkili bir yolu olarak görülen sorgulamaya dayalı öğrenmeyi teşvik etmektedir. Ancak, sorgulamaya dayalı fen sınıflarındaki öğretmen-öğrenci etkileşimlerinin yapısını değerlendiren az sayıda çalışma bulunmaktadır. Sınıf, öğrenciler ile öğretmenlerin etkileşim sürecinde olduğu sosyal bir yer olmasına rağmen, bu araştırma eksikliği sorgulamaya dayalı fen sınıflarındaki etkileşimin doğasına ilişkin anlaşımasını engellemektedir.

Materyal ve Yöntem: Bu temelde, bu çalışma, sınıf içindeki etkileşimsel yapıları ortaya çıkarmak için mikro-analitik konuşma çözümlemesi yöntemiyle sorgulamaya dayalı fen sınıf etkileşimini incelemektedir. Araştırma iki fen bilgisi öğretmeni ve 565 . sınıf öğrencisi ile yürütülmüştür. 12 saatlik sorgulamaya dayalı fen sınıfı etkileşimlerinden oluşan bir veri tabanı, konuşma çözümlenmesi kullanılarak satır satır ve adım adım incelenmiştir.

Bulgular: Bulgular, sorgulamaya dayalı fen uygulamarında etkileşimsel olarak farklı aşamaların olduğunu ve öğretmen-öğrenci etkileşimlerinin bağlama göre değiştiğini göstermektedir. Dersin etkileşimsel olarak farklılaşan bu aşamalarında, öğretmenlerin pedagojik amaçları ve etkileşimli araçların farklılık gösterdiği tespit edilmiştir.

Önemli Vurgular: Bu çalışma fen sınıflarındaki etkileşimsel yapıların ortaya çıkartılmasına ve fen derslerinin etkileşimsel özelliklerinin incelenmesi açısından konuşma çözümlemesi araştırmalarına katkı sunmaktadır.

${ }^{1}$ This paper was prepared from the first author's PhD thesis under supervision by the second author.

${ }^{2}$ Corresponded Author, Kastamonu University, Faculty of Education, Department of Primary Education, Kastamonu, TURKEY; https://orcid.org/0000-0003-40449243

${ }^{3}$ Hacettepe University, Faculty of Education, Department of Mathematics and Science Education, Ankara, TURKEY; https://orcid.org/0000-0003-2003-2520 


\section{INTRODUCTION}

Contemporary science education curricula aim to promote students' use of inquiry to adapt to continually changing and developing information bases (Finlayson et al., 2015; NRC, 2000). Some reports, policy and reform documents have been affecting science education curricula and teaching objectives throughout history. For example, the Sputnik crisis, Beyond 2000 (Millar \& Osborne, 1999), National Research Council Reports (NRC, 1996; 2000) and the Next Generation Science Standards (NGSS Lead State, 2013) have influenced science education perspectives. NRC reports (1996; 2000) have a significant impact concerning science education standards and, in all reports, the relation between inquiry and teaching and learning of science is highlighted. Rocard et al. (2007) also prepared a report for the European Commission which is related to the present and the future of science education. This report acted as a stimulus for inquiry-based science education (IBSE) research and projects, mapping the science education framework and requirements in the modern world. At the end of the report, the authors suggested that inquiry is the focal point of science education.

Accordingly, there is much research (e.g., Abd-El-Khalick et al., 2004; Crawford, 2007; Finlayson et al., 2015; Author 2016; Minner et al., 2010; Sadeh \& Zion, 2009) in this field to investigate different ways to increase practicality in the science classroom. However, despite the significant number of studies, practicality of inquiry remains a challenge as teachers and prospective teachers experience difficulties applying this approach in the classroom (Abraham \& Millar, 2008). Research shows that teachers can respond to the questions regarding the inquiry-based learning approach with appropriate answers 'outside the classroom'; however, they fail to reflect their ideas in their classrooms (Darling-Hammond et al., 2020; Author, 2016). This situation refers to some troubles seen 'in the classroom', which points to a need to investigate them there. Such an investigation can potentially provide rich feedback oriented to bringing new insights into classroom activities, teacher-student interaction, teacher talks, and various classroom-contextual components, especially for understanding what is happening in the classroom. Therefore, this study focuses on teacher-student interaction, mainly through investigating teacher talk and teaching activities in the IBS classrooms. The study's purpose is to conduct a micro-analytic conversation analysis of an IBS classroom to unpack the interactional structure of science classrooms. Furthermore, in line with the general purpose, the paper sets out to propose an interactional definition of IBSE by describing the interactional unfolding of lesson phases and identifying interactional tools and pedagogical aims in a micromoment context.

\section{Classroom Interaction and IBSE}

According to the social constructivist approach, the development of the learner cannot be fully explained only by individual efforts. Vygotsky (1978) stated that two individuals with the same level of Intelligent Quotient (IQ) would have a different degree of learning because of the impact of different social environments on their developments. Therefore, some scholars have focused on classroom interaction to understand meaning-making processes. For instance, Edwards and Mercer's (1987) pioneering research in science education looked at the relationship between the context of lessons and practical activities while talking. Lemke's (1990) seminal work also claims that learning science involves learning to talk science, and he focuses on how students get to talk about science during classroom discourse. Another example is Rocard et al. (2007), who pioneered research on inquirybased learning and established inquiry-based learning as a contemporary research framework and stated that communication is a skill which learners should develop. The increasing research interest in science classrooms shows that the invisible nature of science classroom talk has become more crucial, and there is a need to conduct more research to unpack it.

Classroom interaction is increasingly gaining importance in science education as well as the social sciences. Research in the roles of teachers and students in a socio-cultural environment within the classroom is of utmost importance to improve an understanding of the applicability of the inquiry-based approach (Kelly, 2007; Oliveira, 2010; Windschitl, 2004). Investigating and improving a socio-cultural structure within the classroom is possible through conversation analytic examinations of teacherstudent (Zemel \& Koschmann, 2011) and student-student interactions (Mortimer \& Scott, 2003) in order to reveal their discourse patterns (Lemke, 1990; Mehan, 1979) and analyze the interaction (contact) between participants (Mortimer \& Scott, 2003). Many researchers state that the quality of interaction and discourse in the classroom should be improved to teach science literacy and IBSE (Kelly, 2007, 2014; Lemke, 1990; Mortimer \& Scott, 2003; Oliveira, 2010; Tang, 2016). For this reason, teacher educators suggest some frameworks for teachers, since they are the prominent figures in classroom interaction and discourse. For instance, Mortimer and Scott (2003) suggest a communicative approach that aligns with teachers' purposes, and can also be used for teacher interventions. On the other hand, Walsh (2006) suggests another framework that is oriented towards language classrooms but is often used in other educational disciplines, namely self-evaluation teacher talk (SETT) which emphasizes the notion of classroom interactional competence (CIC). The reflection on teachers' interaction is the central place of the SETT framework

The first influential science classroom discourse research was conducted by Edwards and Mercer (1987). They examined the relationship between the content of science lessons and the practical activities through teacher-student talk. The second highimpact study was Lemke's study (1990) which draws on discourse analysis. According to Lemke (1990), scientific discourse is not merely talking about science, it also means doing science through the language. Thus, it also refers to observing, describing, comparing, classifying, analyzing, discussing, hypothesizing, theorizing, questioning, challenging, arguing, designing experiments, following procedures, judging, evaluating, deciding, concluding, generalizing, reporting, writing, lecturing, and teaching in and 
through the language of science. Lemke (1990) also describes classroom interaction with a triadic framework, Question-AnswerEvaluation.

Mortimer and Scott (2003) conducted similar research, focusing on meaning-making processes. They established links between discourse patterns and the communicative approach, which affects meaning-making processes in the science classroom. More recently, Kaya et al. (2016) have investigated secondary school science classrooms through teaching the nature of science. The researchers drew on discourse analysis to examine teacher talk, and they concluded that a discourse pattern which is triadic, chained and adjacently paired, can explicitly change the nature of science teaching and learning processes. Tang (2016) examined the relationship between the communicative approach to classroom talk and the modes of representation used by science teachers. Jin et al. (2016) investigated how physics teachers structured classroom discourse to promote the cognitive and social aspects of IBSE. The research was conducted with 17 physics teachers who were actively involved in teacher education at the university level and teacher training activities in local school quarters. Considering the social aspect of the inquiry, the teachers interacted frequently with the students in a class. However, it was found that facilitating conversations among students and prompting students to talk about their ideas are quite challenging. Besides, Jin et al.'s (2016) research empirically showed that teachers often asked students to follow the procedures of scientific experiments rather than engaging them in active thinking. Teachers were also inclined to associate hands-on activities with inquiry-based teaching, and hence engaged students in activities that were hands-on but not minds-on.

However, there are some studies on the interactions in classrooms, and the analysis in the existing studies has superficial transcriptions and unconvincing patterns. Looking at these studies (Lemke, 1990, Mortimer \& Scott, 2003; Rymes, 2008; Ryder \& Leach, 2008; Windschitl, Thompson, \& Braaten, 2008), it is seen that superficial transcriptions and generic structures (e.g., IRF/E, IRFRF) have been used to gain an understanding of these settings. The researchers in the line of research that has been given so far (e.g., Kelly, 2007; Kelly \& Crafword, 1997; Lemke, 1990; Mortimer \& Scoot, 2003; Ryder \& Leach, 2010; Rymes, 2008; Windschitl, Thompson \& Braaten, 2008) seem to analyze classroom discourse based on orthographic transcriptions of classroom interactional instances and examine the data to infer some patterns. They bring evidence to classroom contexts using these relatively minimally detailed transcripts, which might eventually lead to a lack of understanding of the discourse and communication, as well as a lack of identification of the context.

In addition to orthographic transcriptions of talk, it is also of utmost importance to include intonation, stress, interruptions, pauses, gestures, and the physical context in detail in the transcripts (Sert \& Seedhouse, 2011; Sert, 2013; Walsh, 2011). Therefore, the studies that investigate the interactional skills among teachers and students and discourse in science education are required to address this multitude of interactional details in the analysis of discourse rather than transcription analysis. Notably, in the last decade, ethnomethodological conversation analysis has frequently been used in classroom interaction studies (e.g., Seedhouse 2004; Evnitskaya \& Morton 2011; Sert \& Walsh 2012). The first research which draws on CA is Mchoul (1978) regarding the organization of turns during the formal talk in a classroom. He investigated sequential organization rules in classroom settings and found that they are different from informal speech exchanges regarding turn-taking and turn allocation, and also that teachers organize their rules. Mchoul (1978) used audio and video recordings of teacher-fronted classrooms, and he discovered some rules in terms of management of turn-taking in classroom interaction.

Following Mchoul (1978), much research has explored classroom interaction types, and has drawn on a micro-analytic perspective. The bulk of research adopting a CA perspective has been particularly oriented to language classrooms (e.g., Brandt, 2011; Evnitskaya \& Morton 2011; Kääntä, 2010; Markee, 2000; Mortensen 2008, 2009; Mortensen \& Hazel 2011; Seedhouse, 2004; Sert, 2011; Sert, 2015; Sert \& Walsh 2012). Nevertheless, there is some research carried out in the field of science education related to Content and Language Integrated Learning (CLIL) (e.g., Evnitskaya, 2012; Mercer, Dawes, Wegerif \& Sams, 2004; Morton, 2012). However, research on interactional organization of science classrooms (e.g., Duschl \& Osborne, 2002; Kelly \& Chen, 1999; Kelly, 2007; Leach \& Scott, 2002; Lemke, 1990, 2001; Mortimer \& Scott, 2003; Roth, et al., 2011; Windschitl, Thompson, \& Braaten, 2008; Urmeneta, 2008; van Aalst \& Trounog, 2011) has drawn on discourse analysis rather than the micro-analytic perspective. The principal methodological power of the micro-analytic CA, apart from discourse analysis, is to bring robust evidence to learning and comprehension at the micro-level in the interaction of teachers and students. Although the discourse patterns reflect the interaction in classrooms to a certain extent, they still need to be complemented with data and robust analytic evidence. Therefore, it is considered that micro-analytic methods are necessary for science education, including CA which provides an indepth analysis. With this research gap in mind, this study set out to adopt a CA-based approach for the examination of science education settings, given that CA provides evidence of discourse patterns such as IRF (initiation-response-feedback; Sinclair \& Coulthard, 1972) or its modifications. However, these patterns have not received enough research attention in various classroom interactional settings (Sert, 2011). These generalizations can give an overview to help us understand classroom interaction and sequential organization.

Given that it will add a new dimension to these issues, this research is deemed essential and valuable. At the same time, it will pave the way to use by achieving the purpose and simplifying the applicability of an IBS education informed by the data and

| Kastamonu Education Journal, 2021, Vol. 29, No. 3 | 
research evidence. This study will describe classroom interaction in the IBS classroom and look more closely into interaction, adopting a conversation analytic perspective in line with the following research questions:

1. How is teacher-student interaction sequentially organized in IBS classrooms?

2. What are the pedagogical aims used by teachers in IBS classrooms?

3. Which are interactional tools used by teachers to actualize pedagogical aims in IBS classrooms?

\section{METHODOLOGY}

The research reported in this paper is part of a study (Kaya, 2017) conducting a micro-analytic investigation of an IBS classroom to unpack the interactional structure of science classrooms. This study examines IBS classroom interaction by the CA method to reveal the interactional phenomena within the classroom. CA has the potential to reveal the interactive nature of science classes by examining naturally evolving interaction data from a data-driven and participant-focused perspective, focusing on the participants' moments of success in social actions.

Empirical data analyzed in this study come from two different classrooms as part of a larger corpus. The data were gathered during the implementation of a science lesson for a term that has four different science subjects at 5th level. This level is the first stage of the lower secondary school in the Turkish educational system. Furthermore, the implementations were conducted at the same level in two different state schools in Ankara, Turkey. The whole corpus includes conversational data that come directly from science classrooms. The corpus consists of audio and video recordings of 24 science lessons, each of which is approximately 45 minutes long. So, there are a total of 12 hours of recordings.

\section{Conversation Analysis (CA)}

The current study employs micro-analytic conversation analysis (Sacks, 1992), a methodology which has emerged from ethnomethodology (Garfinkel, 1964). It should be noted that within the research, the terms micro-analytic analysis and CA are used interchangeably. CA is mainly used for examining structures and patterns of interaction in everyday talk and institutional contexts. So, it can be described as "the interaction order", in line with Goffman (1983). According to Sidnell (2010), CA is an approach within the social sciences that aims to "describe, analyze and understand talk as a fundamental and constitutive feature of human social life" (p.1).

Ethnomethodological CA is mainly oriented to developing an understanding of how this order is achieved in social interaction, and it is a data-driven methodology based on micro-analytic studies (Sidnell, 2010). The analysis in this research employs the methods and principles of CA to "uncover social actions through observing and describing turn-taking, repair and preference organization practices" (Sert, 2011, p. 6). "Unmotivated looking" is the crucial principle of CA methods and a starting point for the examination of data to discover what is happening (Liddicoat, 2007). Unmotivated looking involves the analysts' preliminary examination of the data to reflect the participants' points of view, rather than looking for a pre-identified or pre-defined theoretical phenomenon. Therefore, the first and essential step of the analysis is to reveal some phenomena through an unmotivated look at the recorded data. In this study, unmotivated looking is employed for the initial treatment of recorded IBSE classrooms. When a phenomenon emerges from the corpus, it is investigated for further occurrences in other recordings, to discover a pattern in teacher-student interaction. The data also include multimodal features of classroom interaction. However, conducting a multimodal analysis is beyond the scope of the current study, mainly due to some technical problems with the recordings and also to maintain a more specific research focus. Nevertheless, the study addresses multimodal features to increase the readability of extracts and reflect the sense-making mechanisms in interaction.

\section{Participants}

The participants were two science teachers at the secondary school science level and 56 (11- or 12-year-old) students in these teachers' classes who were attending their first compulsory secondary education year. Teachers and classes use Turkish at the secondary level in Turkey.

The main focus of this research is on two science teachers who were selected through purposeful sampling. The researcher specified some features before choosing the teachers, such as keeping an open mind for academic and professional development, teaching science at the 5th-grade level, and willingness to do group work. First of all, possible school options were determined for implementation, and then school visits were carried out to inform the principal and science teachers about the details of the research. During this process, the researcher mentioned the research aims and his expectations from the teachers. Following the explanation of the process, the researcher checked whether they would take part in the research as volunteers. Moreover, signed consent forms were collected from participants before the implementation. A similar process was conducted for learners and their parents. Merve and Büşra (pseudonyms) were the main participants in the research. 


\section{Data Collection}

The data collection process is an integral part of conversation analytic research for identifying verbal and non-verbal actions during an interaction (Jenks, 2011). For this reason, all of the data collection tools were explained and negotiated in terms of classroom settings at the kick-off meeting with the teachers. Three cameras, positioned as shown in Figure 1, recorded the lessons' entire duration.

The researcher did not participate in the lesson to avoid interfering with its naturality. Labov (1970) refers to the negative impact of cameras, and an observer's or researcher's presence in recorded settings, as the observer's paradox. The cameras were set up with an adjustable tripod for every lesson and fixed according to the learner seating plan without any intervention by a controller to minimize negative effects. However, the absence of a researcher to adjust the cameras during the class time caused the loss of some data due to teacher movements in the blind spots. Moreover, in some cases, the cameras did not record the participants' voices clearly because of multilogue interaction, choral responses, and softer sounds. With these factors in mind, the first inquiry-based lesson included three cameras, but this session was not recorded, to allow the participants to get used to the presence of cameras.

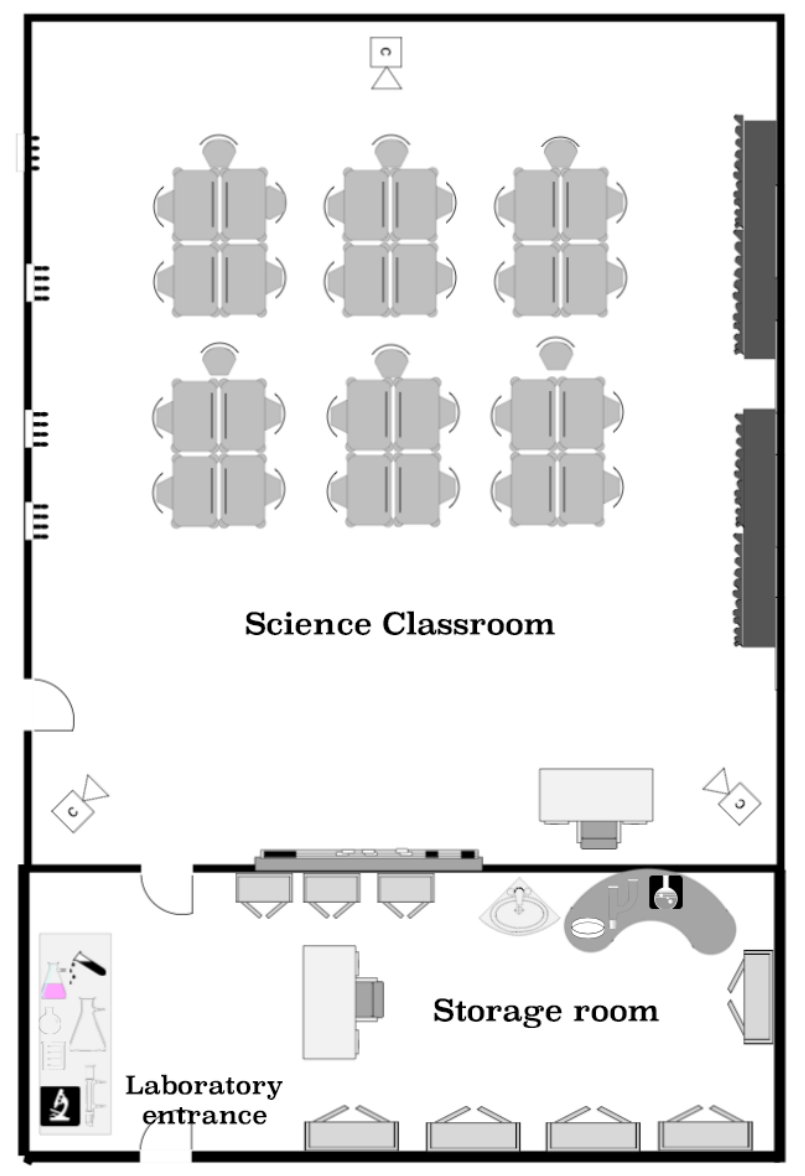

[Figure 1. Classroom settings and location of cameras]

\section{Data Treatment}

For representational purposes, each extract in the paper has an identification code for increased readability of the following analyses. For example, Extract 3: Mrv_ax_Isx, short identification of extract, [time span], where 3 stands for the number of extracts in the whole collection, making it easy to access it in the database and Mrv or Bsr show the teacher's name in the collected data. Following the teacher codes, an inquiry-based task name is given; for instance, "ax" expresses the "sound cups" in the "Propagation of Sound and Light" unit. The "Isx" stands for the classification of the lesson section instead of giving the exact minute. Following the lesson phase demonstration, a brief explanation is given to clarify the subject of the sequence or the main topic of the analysis. The last code in the identification system is the time interval between the opening and closing of an extract in the given lesson phase rather than the entire lesson time. Annotation of data is another significant step while building a database and building a collection of the phenomenon being investigated.

All transcriptions were in the Turkish language, and the data were translated into the English language only for the extracts used in the paper. Due to the difficulties of translation from the primary language to another language, there is no consensus about translation among CA scholars. On the one hand, some of them advocate that all transcripts should be translated word by word, concerning translations of the idiolects (Jenks, 2011). On the other hand, some others maintain that translations of any 
transcription might harm the nature of data and the interaction language (ten Have, 2007). Furthermore, CA studies include many notations to present verbal or non-verbal actions, and these notations can be used at the beginning, in the middle, or at the end of a word. Therefore, showing notations in translated turns is troublesome concerning the precision of the moment of unfolding actions. With these considerations in mind, the data translated a turn based on idiolects to provide an overall understanding of the data for all researchers and target groups.

\section{Reliability, Validity and Limitations}

Reliability is a crucial concept for CA studies too, as Seedhouse (2004) states: CA research is based on the recordings of the interactional episodes for further examination. It also underscores CA studies' reliability, in that these recordings capture as much of the interaction as possible. For instance, all the participants should be recorded during the communication, and the recordings should not consist of only audio or video. To this end, audio-video recordings are a basic requirement for reliability in CA research. Besides, choosing an excerpt or the micro-moments and presenting quality representations are of utmost importance to ensure the study's reliability.

CA researchers (Jenks, 2011; Heath et al., 2010; Sert, 2011) dwell on the camera locations regarding interaction, participant, natural settings, and different angles. With this concern in mind, the first author located three fixed cameras with three tripods to view the participants from the best angles possible (see Figure 1). One camera is located at the back of the classroom to record the teachers, but teachers usually move around in inquiry-based learning classrooms. Therefore, it was fixed near the blackboard located at the back of the classroom. Two cameras were set up in the left and right corners at the front of the classroom, and they focused on the students and student groups.

Data analysis and data representations are fundamental validity factors of CA research (ten Have, 2007). Moreover, Seedhouse (2004) focuses on the validity concern under four different dimensions, and he links them with the objectivity and credibility of the research. These dimensions are internal, ecological validity, construct validity and generalizability. The current research draws on the next turn proof procedure to show participant orientations based on speaker actions, and all claims are grounded in an "emic perspective". Hence the findings are entirely open for examination by other analysts. Ecological validity is "normally concerned with social research which is conducted in experimental and laboratory-based settings, which may not be transferable" (Brandt, 2011; p. 57). Data comes from classroom settings that are not scripted environments, and participants' actions are observably context-renewing. However, one concern might be a possible departure from natural occurrence due to recording interactions with three cameras.

\section{FINDINGS}

Institutional interactions are investigated in terms of specific features such as turn-taking, turn design, sequence organization, lexical choice and asymmetry of roles (Heritage, 1997). Through the first section of the analysis and the findings section, all of these features will be exemplified in IBS lessons and micro-moments of the lesson called 'lesson phase' (LS) in the whole study. It will also focus on how a lesson is initiated, maintained and closed by the teacher within the IBSE. The second question is related to describing and revealing teachers' pedagogical aims and interactional tools oriented to the mediation of emerging educational goals. The second question will also build upon the findings related to the first research question. The pedagogical aims and interactional tools will be discussed considering the different micro-contexts throughout a lesson.

IBS lessons are divided into sub-sections based on some theoretical assumptions (Author, 2016; Pedaste et al., 2015). However, some scholars are unaware of the different stages of inquiry processes in the lesson (Minner et al., 2010). During the microdetailed analysis, we realized that the teachers divided the inquiry lessons into three different sections: the first section is related to "initiating the inquiry", or a warm-up section before teamwork or investigation of the research question. The second is the primary investigation process, which includes teamwork and experimenting; this section is called "focusing on the investigation". The third section is the "sharing of understanding" time after the inquiry process, which comprises sharing the findings, comparing the investigation process and outputs, discussing with peers, and teacher requests for explanation or checking for understanding. Furthermore, sequence organization, turn-taking structure, and preference organization become distinct in these lesson phases.

Through various teaching series, teachers' pedagogical aims and interactional tools drawn on for implementation purposes were unpacked. To this end, every lesson phase in this section can be investigated in terms of teachers' pedagogical foci and the interactional resources that they deploy. Teachers draw on some pedagogical focus/aims/goals to get the highest level of learning objectives. The learning focus is defined as "task as workplan" (Breen, 1989), "task as a process" (Seedhouse, 2004) or "academic task structure" (Erickson, 2004), while the pedagogical focus is referred to as "task-in-process" (Schwab, 2011). Thus, the learning aim has a static structure, but the pedagogical aim is dynamic. Teachers manage the lesson phases depending on the learning goal, pedagogical aims, and interactional tools. The term 'interactional tools' is favored in the study rather than 'interactures' to refer to the relationship between the lesson phase and its componential interactional tools. An interacture can be defined as a particular tool which 'belongs to' or is typical of the lesson phases. The pedagogical aims and interactional tools were also given in every lesson phase section below. 


\section{The Initiating the Inquiry Lesson Phase: Interactional Features and Pedagogical Aims}

The inquiry lesson's initiating phase has been defined as the first step of an IBS lesson since it covers the beginning of the task before the investigation process. It can be seen as preparation for the scientific investigation in terms of a research question or a scientific topic. Therefore, this lesson phase requires different patterns, pedagogical aims, sequential organization, and distribution of teachers' and students' roles for the following parts of the lesson phase. The lesson phase frequently has a recurring pattern that reveals how the lesson will go on, thus hinting at the process's general structure. Therefore, the beginning of the inquiry lesson phase can be interactionally identified. The lesson phase definition emerged from the data inductively, as shown in Table 1 from the beginning to the end.

Table 1. Initiating the inquiry lesson interactional structures

\section{Lesson phase}

\section{Interactional features}

1. Teacher's questioning process about students' background knowledge or previous lessons as an initiator of the sequence.

Initiating the 2. Responses elicited from more than one student relevant to teacher requests.

inquiry $\quad 3$. Teacher's avoidance of the evaluation of students' contributions.

4. Classroom discourse and discussion continued on the research question between teacher and learners or teacher's transmission of the research question.

5. In the final part of this lesson phase, participants get through the investigation process.

\begin{tabular}{|c|c|c|c|c|c|}
\hline Lesson phase & & $\begin{array}{l}\text { Pedagogical Aims } \\
\text { (pa) }\end{array}$ & & $\begin{array}{l}\text { Interactional Tools } \\
\text { (it) }\end{array}$ & Descriptions \\
\hline \multirow{7}{*}{$\begin{array}{l}\text { Initiating the } \\
\text { inquiry }\end{array}$} & & & & & Teacher turn of more than one clause. \\
\hline & pal. & To introduce the IBS activity & it1. & $\begin{array}{l}\text { Extended teacher turns } \\
\text { which uses explanation or }\end{array}$ & \\
\hline & par. & $\begin{array}{l}\text { Checking and displaying the } \\
\text { answer to elicit responses in } \\
\text { relation to previous lesson or } \\
\text { scientific subjects }\end{array}$ & it2. & $\begin{array}{l}\text { instruction } \\
\text { The use of transition } \\
\text { markers }\end{array}$ & $\begin{array}{l}\text { Turn openings or topic changes markers } \\
\text { (e.g., all right, yes, now) and attention- } \\
\text { getter. } \\
\text { Asking questions to which the teacher }\end{array}$ \\
\hline & \multirow{2}{*}{ pas. } & \multirow{2}{*}{$\begin{array}{l}\text { To enable increased learner } \\
\text { participation }\end{array}$} & it3. & Known-answer question & knows the answer. \\
\hline & & & it4. & $\begin{array}{l}\text { Paraphrasing of learner } \\
\text { contributions }\end{array}$ & $\begin{array}{l}\text { Declaration of the learners' response } \\
\text { within some lexical changes }\end{array}$ \\
\hline & pat. & $\begin{array}{l}\text { Ask some questions to prepare } \\
\text { for the investigation process }\end{array}$ & $i t 5$. & Teacher's allocation & $\begin{array}{l}\text { Selection of the next speaker among the } \\
\text { learners by bidding or direct nomination }\end{array}$ \\
\hline & pas. & To transmit information & it6. & Absence of feedback & $\begin{array}{l}\text { Not giving feedback following the } \\
\text { learners' explanation }\end{array}$ \\
\hline
\end{tabular}

To illustrate the initiating an inquiry lesson phase, Extract 1 is chosen from the corpus. In Extract 1, Busra draws on student experiences as a warm-up activity before focusing on the investigation stage. Extract 1 illustrates an example during which the participants talk about their experiences concerning the highest hill they have ever seen. Before the extract, the teacher asks a question, "which is the highest hill you have ever seen?" to elicit responses based on the learners' prior knowledge. The question works as an initiator of the sequence. The answers are elicited from more than one student (line 37-48, 49-70, 71).

Extract 1: Bsr_a4_ls1, Teacher (Tchr), Yade and Cenk talk about their experiences concerning the highest hill they have ever seen. [01:02.0-01:49.5]

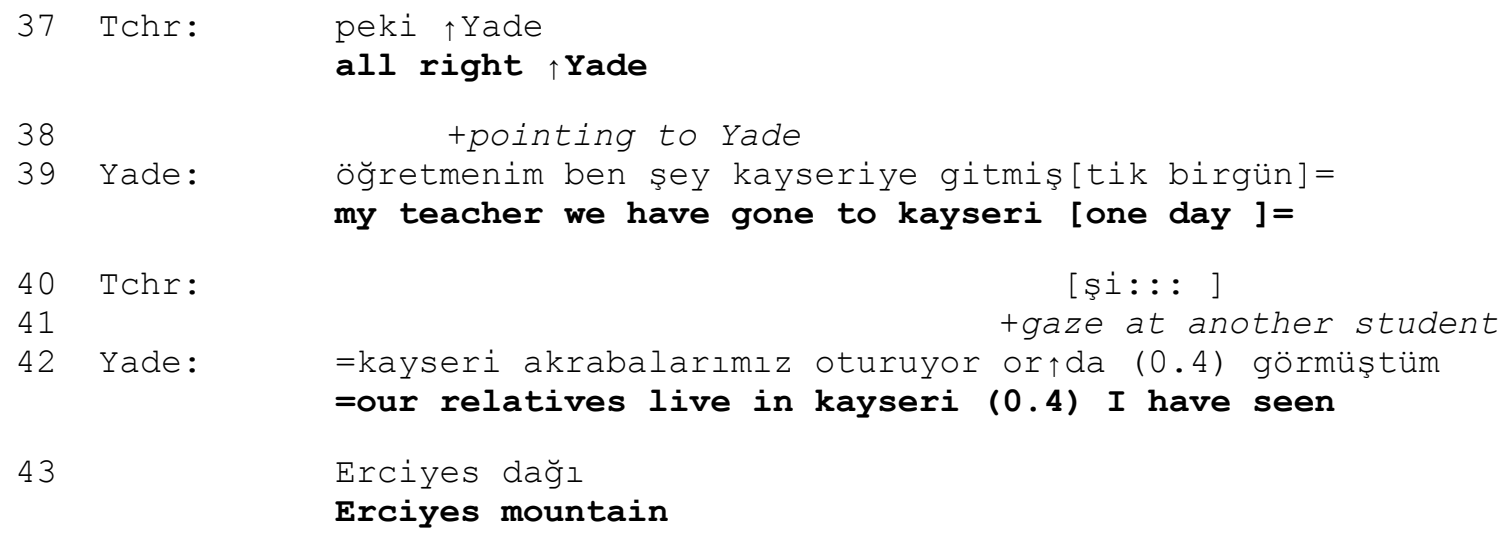






Extract 1 consists of two different sequences between Teacher-Yade (line 37-48) and Teacher-Cenk (49-68). Furthermore, a new sequence starts with selecting a speaker for the same question at the end of the extract. Before line 37, a student tells her experiences, and the teacher produces a 'compliance token' (Schegloff, 2007), "all right", to display understanding and allocate the turn to a new speaker without any evaluation of the previous learner's contribution. After the marker, the teacher assigns the turn (line 37-38) to Yade who bids for the floor by raising her hand to explain her experience concerning the requested topic. Therefore, Yade tells her own experiences about the highest hill she has ever seen, between lines 39 and 43 . The learner's turn emerges as the second pair part of the sequence. When Yade finishes the turn, the teacher asks a question (hmm you saw Erciyes, all right, all right, did you see its highest point?) as a post-expansion (FPPpost) which functions to shape the learner contribution that is used as the third turn of the IRF pattern (Jacknick, 2011) (line 45-47). However, Yade does not give any further information (I didn't see it), and the teacher allocates the turn (line 47 and 48 ) to Cenk, who bids for the floor by raising his hand. During this sequence, the teacher does not rework the base first pair part, but Cenk responds to the question. Cenk constructs a turn construction unit that includes a hesitation marker (ei::) and a word (saklıkent), which is the name of a ski resort area, in line 52. 
Following this turn, there is a long silence (line 53) and the teacher looks away as if she is thinking about "saklıkent". This silence may be an indicator of an open question, repair, or post-expansion. So, the teacher asks a question to clarify the location of the hill in line 54.

Moreover, she asks more questions (line 58,65 ) and requests an explanation (line 60). These turns include two actions, namely request for the elaboration on the students' talk and shaping learner's contributions, thus being 'double-barreled' (Schegloff, 2007), which denotes more than one action to an utterance. After the extract, the teacher continues to elicit student experiences regarding the main topic, and then she passes to the research question that constitutes the learning aim. In the whole process, the teacher avoids any verbal evaluation of students' contributions, in order to elicit more responses. Walsh (2006) notes that the less the teacher gives evaluative responses in the discussions, the longer the controversial topic lasts. Besides, Sert (2015) explains the balance between the timing of evaluation, and if the teacher does not give the right answer immediately, it provides communicative space for other students.

When Extract 1 is analysed with a focus on pedagogical aims and interactional tools (Table 1), the teacher's pedagogical focus dominates the whole series by asking questions to lay the ground for the investigation process and to enable increased learner participation. Throughout the extract, the teacher draws on learner experiences and uses information-seeking questions instead of known-answer questions. The interaction which occurs between the teacher and Cenk emerges differently from the interaction between the teacher and Yade. Cenk starts his turn with a hesitation marker "ei:" and just says "saklıkent", which is the name of the mountain that is the highest he has ever seen (line 52). However, a long silence follows his turn (line 53). The teacher asks a question to clarify the location of the hill in line 56.

Moreover, she asks more questions (line 58,65) and requests an explanation (line 60). All teacher turns have multitasked features that shape learner contributions and elaboration on student talk. At the end of the sequence, the teacher is still seeking increased student participation, but she does not make any evaluations or give feedback. Furthermore, she allocates the turn to another student to maintain the pedagogical aim. This endeavour also serves the second educational goal, which is to ask a question to prepare for the next lesson phase; in other words, the "focusing on the investigation" sequence.

The initiating of the inquiry lesson phase consists mainly of a question-answer adjacency pair, as is the case in traditional classrooms. A question utterance creates the first pair part (FPP) of a sequence and is frequently constructed by the teachers (e.g. Extract 1). An answer is the second pair part (SPP) of the line as a conditionally relevant constructional unit of an adjacency pair. Students build SPP, and teachers try to elicit multiple SPPs (e.g., Extract 1) throughout the lesson phases, which refer to more than one appropriate pair (Schegloff, 2007) or a candidate answer (Koole, 2010) in response to the same FPP. For this reason, a question is reworked after a possible explanation is provided through a multilogue discussion, or a new recipient is selected without reworking or paraphrasing the FPP (e.g., Extract 1).

\section{The Focusing on the Investigation Lesson Phase: Interactional Features and Pedagogical Aims}

The "focusing on the investigation" lesson phase is located in the middle of the IBS lessons, and it is also the longest part of the lesson time. Throughout this lesson phase, students engage in an experimental process to come up with evidence, results, and implications based on a research question. Furthermore, the learners collect data and make inferences as a preparation for the "sharing understanding" lesson phase. The "focusing on the investigation" section has several interactional characteristics, which frequently occur with a recurring classroom discourse pattern, as seen in Table 2.

Table 2. The "focusing on the investigation" phase of the inquiry lesson

Lesson phase

Interactional features

1. Following the beginning of the investigation process, the teacher observes while the learners work on the material and ask questions, or the learners ask for help and guidance from the teacher.

Focus on the investigation
2. Teacher's questioning or learners' requests are mainly related to possible error sources. When the teacher realises there is trouble, he/she delivers some guidance or works as a group member.

3. If the problem is common, the teacher makes an announcement to the whole class.

4. The teacher moves to another group (teacher walks around the research group).

5. At the end of the focus on the investigation process, instructions are given to enable a transition to the last part (sharing understanding) of the inquiry science lesson.

\begin{tabular}{|c|c|c|c|c|c|}
\hline Lesson phase & & $\begin{array}{l}\text { Pedagogical Aims } \\
\text { (pa) }\end{array}$ & & $\begin{array}{l}\text { Interactional Tools } \\
\text { (it) }\end{array}$ & Descriptions \\
\hline \multirow{3}{*}{$\begin{array}{l}\text { Focus on the } \\
\text { investigation }\end{array}$} & pa6. & $\begin{array}{l}\text { To organise the physical learning } \\
\text { environment and rules }\end{array}$ & it7. & $\begin{array}{l}\text { An absence of learner } \\
\text { contribution }\end{array}$ & Short or rarely learners' turn. \\
\hline & & $\begin{array}{l}\text { To help students concerning } \\
\text { material problems }\end{array}$ & \multirow[t]{2}{*}{ its. } & \multirow{2}{*}{$\begin{array}{l}\text { A single teacher turn which } \\
\text { uses instructions }\end{array}$} & \multirow{2}{*}{$\begin{array}{l}\text { A single, extended teacher turn which } \\
\text { uses explanations and/or instructions }\end{array}$} \\
\hline & pas. & $\begin{array}{l}\text { To ensure following the } \\
\text { instruction }\end{array}$ & & & \\
\hline
\end{tabular}


pa9. To elicit responses about the material or process

pa10. To check the investigation process while students are working

pa11. To introduce the research process it9. The use of attention-getter devices

it10. Information-seeking question

it7. Absence of teacher allocation
Imperatives and high-volume expression turn-initial position

Genuine questions to which the teacher does not know the answer.

Turn-taking without teacher's allocation or nomination.

To illustrate this lesson phase, Extract 2 is chosen from the corpus. In Extract 2, the teacher works as a team member and finds out the problem related to the lighting of the lamp. She steps in to draw students' attention to the connection of the electric circuit. At the beginning of the sequence, the teacher observes a group while they are working on the electrical circuit (line 25). Then she asks a question (FPP) to understand what they have done during the research process (line 26). Arya responds to her with "yes" (SPP). Following the answer, the teacher asks to see the circuit in line 28. Furthermore, she handles the circuit component (line 29-30) and requests an explanation (but why doesn't it work) for trouble related to the practical problem (line 31). However, nobody takes the turn, so the teacher works as a group member, and she identifies the trouble (the cable ends have not connected) (line 33). Then, the students undertake some tests to fix the connection of the cable (line 34). While they are working on the material, the teacher observes the students' interventions, and she gives further instructions (lines 35, 37). Following the short sequence, the teacher again steps into the students' work and takes the crocodile clips to make the connection between the cable and the socket (lines 38-39, 42). While the teacher works on the material (line 45-47), Omer joins the interaction and expresses his idea (my teacher, the problem is there-there) about the problem (line 45, 50). Then Omer displays his intention to interfere with the teacher's work between lines 52 and 54, but the teacher prevents the student's contribution with a strongly negative assessment token (line 55). The students complain about the teacher's intervention in their investigation process, and she verbalises her situation in line 56 . The teacher tries to help the students, although the students are disturbed by the teacher's working as a group member.

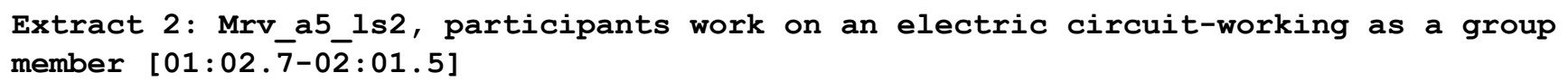

(1.8) ((Teacher touches circuit components which are constructed by group members))

33 Tchr : bunların uçları $\uparrow$ BAĞLANMAMIŞ BAĞLANMAMIŞ the cable ends haven't connected

(4.0) ((Students do some tests for connect to cable))

35 Tchr : bağla

connect it

(1.6)

37 Tchr : bunu bunu bağla (buraya)

connect this this (there)

( (Teacher struggles to fix the crocodile clips

tight $\left.I_{y}\right)$ )

(17.3) 


\begin{tabular}{|c|c|c|c|}
\hline 41 & Tchr & : & $\begin{array}{l}{ }^{\circ} \text { bunu ( ( )) bă̆la } \\
{ }^{\circ} \text { connect this }\end{array}$ \\
\hline $\begin{array}{l}42 \\
43\end{array}$ & & & $\begin{array}{l}\text { ((Teacher connects the cables but lamp doesn't work)) } \\
(3.6)\end{array}$ \\
\hline 44 & Tchr & : & $\begin{array}{l}\text { bunu yanlış } \uparrow \mathrm{m} \text { bağla } \operatorname{mışsınız\uparrow =} \\
\text { you connected it wrong } \uparrow=\end{array}$ \\
\hline 45 & Omer & : & $\begin{array}{l}{ }^{\circ} \text { hocam (şurasında sorun var) şurda şurda }{ }^{\circ}(\text { ) } \\
{ }^{\circ} \text { my teacher, the problem is there-there }{ }^{\circ}(\text { ) }\end{array}$ \\
\hline 46 & Tchr & : & $\begin{array}{l}\text { >tamam tamam< bu boz } \uparrow u k \\
\text { >ok ok< this is broken }\end{array}$ \\
\hline $\begin{array}{l}47 \\
48 \\
49\end{array}$ & & & $\begin{array}{l}\text { ( (As soon as she finished this turn, she turns her } \\
\text { head to the teacher's table that is used as an equipment } \\
\text { table and then she tries to fix the cable)) }\end{array}$ \\
\hline 50 & Omer & : & $\begin{array}{l}\uparrow \text { Öyle birşey olmuyo: : } r= \\
\uparrow \text { it isn't like that= }\end{array}$ \\
\hline 51 & Tchr & : & $\begin{array}{l}\text { tamam tamam (bir dakka) } \\
\text { ok ok (just a moment) }\end{array}$ \\
\hline $\begin{array}{l}52 \\
53 \\
54\end{array}$ & & & $\begin{array}{l}\text { (1.0) ((Omer interferes with the teacher's work, he uses } \\
\text { hands to touch the cable, tries to fix the cable problem and } \\
\text { he says something. But we don't hear what he says)) }\end{array}$ \\
\hline 55 & Tchr & : & $\begin{array}{l}\uparrow \text { dur işte: (.) dur= } \\
\uparrow \text { stop (.) stop= }\end{array}$ \\
\hline $\begin{array}{l}56 \\
57\end{array}$ & & & $\begin{array}{l}\text { ((Teacher fixes her gaze on Derya and she } \\
\text { turns her body posture to Derya)) }\end{array}$ \\
\hline 58 & Derya & : & $\begin{array}{l}=\text { bende }>\text { anlamak }<\text { istiyor }[u m= \\
=\mathbf{i} \text { would also >understand }<\text { it }\end{array}$ \\
\hline 59 & Tchr & : & $\begin{array}{l}\text { [yapmaya calışalım yani } \downarrow \\
\text { [so let's try }\end{array}$ \\
\hline
\end{tabular}

The section shows different pedagogical aims and interactional features (seen in Table 2) concerning both teacher-student and student-student interactions. At the outset, the lesson phase mainly contains inquiry processes of research questions based on a research plan that can be provided by the teacher or can be learner-driven. The teacher's strategy, in general, is related to organising the investigation environment and ensuring learners do the research regardless of encountering failures in terms of the output. For this reason, the teacher guides the students to manage the research processes and accomplish a transition into sharing their understanding of the lesson phase. Moreover, the teacher studies with the learners as a peer or mentor, which includes the resolution of a source of trouble, and turns it into a success.

In Extract 2, the teacher observes the students while they are working on the material, and she wants to track the progression of their investigation. She realises some difficulties related to the lightening of the lamp (line 31) and starts working as a group member to proceed to the next step of the investigation process. Thus, at the beginning of the extract, the teacher's pedagogical focus is to check the inquiry process while students are working on the material (line 24-33) and following the checking of the process the teacher changes the pedagogical aim to help the students engage in physical problems (line 35-59). Throughout the sequence, the teacher manages both interaction and implementation processes with a single teacher turn (line 33, 41, 44, 46, 51, 55) which she uses for explanation and instruction given as interactional tools. As a consequence of this, learner contribution is limited and blocked by the teacher (line 46, 51, 55).

Sequence opening of the extract is made with the teacher's question to find out whether the investigation is finished (line 26) in line with the pedagogical aims. Arya says "yes teacher" to provide an affirmative response, oriented to finishing the investigation. The teacher wants to see the bulb light up (line 28), but it does not work. Moreover, she realises there is a problem and touches the circuit components that are constructed by the group members. The teacher asks an information-seeking question "Why does it not shine?" to elicit responses concerning the material and process. Nobody answers, and then the teacher changes the pedagogical aim to help the students engage in the physical problems following line 35.

Moreover, the teacher works as a group member to find the problem with the circuit. Thus, she operates on the circuit to fix it (line 37-41). Despite the teacher's attempts, the electric circuit does not work (line 42). Therefore, she identifies another possible source of trouble in line 44 and asks a question to the group members, "Did you connect it incorrectly?". Omer answers the question and explains where the problem is, and the student insists on the trouble source (my teacher there is a problem therethere) in line 45. The teacher acknowledges the student, saying, "ok ok this is broken" when she touches a crocodile cable in line 
46. Even though the source of the trouble has been found, the teacher tries to fix it rather than changing it (line 47-49). Furthermore, Omer shows disagreement and explicitly expresses it, saying "it is not like that" in line 50 . The teacher rejects this learner contribution despite the absence of learner contributions up to that point.

The "focus on investigation" lesson phase is mainly based on question-answer adjacency pairs in this phase. However, it is different from the initiating of an inquiry lesson phase in that the teacher does not always produce the first pair part, and so the second pair part varies depending on who initiates the sequence (e.g., Extract 2). Furthermore, the third level of the sequence is performed by a participant in the form of an "inverted IRF" pattern (Waring, 2008) which frequently occurs in and through the focus on the investigation process. Besides, before the FPP, the teachers draw on a transitional marker (e.g., Extract 2) as an attention-getter (Pekarek-Doehler \& Berger, 2015) for the opening of the sequence oriented to the students' work on the materials within a small group, as though almost isolated from the other parts of the classroom. For that reason, sequence organisation unfolds with a structure that proceeds as follows: transition marker (for opening the sequence)- initiation (FPP)response (SPP)- and follow-up/feedback.

\section{The Sharing of Understanding Lesson Phase: Interactional Features and Pedagogical Aims}

The "sharing of understanding" lesson phase is the last part of an inquiry-based lesson, and two previous lesson phases shape it. Moreover, in this section research questions, discussion of the scientific concept and teaching time also come to an end. Against this background, it can be seen as the most crucial part of the construction of learning and for realising IBS lesson aims. The general structure also points to a frequently encountered pattern based on the science classroom data, as seen in Table 3.

Table 3. The "sharing of understanding" phase of the inquiry lesson

Lesson phase

Interactional features

1. The teacher initiates the lesson phase with a request for presentation of the investigation process. Almost all groups present their findings.

Sharing of 2. Following or during the presentation, the teacher or peers ask questions,

understanding $\quad 3$. Learners explain their process or respond to the question,

4. The teacher paraphrases student contributions and enacts new group selection

5. The teacher or peers evaluate student explanations and presentations

6. Giving feedback and topic shift

$\begin{array}{cccc}\text { Lesson phase } & \begin{array}{c}\text { Pedagogical Aims } \\ \text { (pa) }\end{array} & \begin{array}{c}\text { Interactional Tools } \\ \text { (it) }\end{array} & \text { Descriptions }\end{array}$

pa13. To check whole group understanding

pa14. To evaluate learner contributions

pa15. Giving learning space for students to elicit a clear answer

pa16. To elicit responses in relation to the findings

Sharing of understanding pa17. To select more than one student for learner contribution

pa18. To ensure using scientific language

pa1 9. To give a chance for group presentations

pa20. To find out arguments concerning the learners' claim it13. Information-seeking question

it14. Paraphrasing of learners' contribution

it15. Confirmation check for the previous speaker or whole class

it16. Content feedback

it17. Reformulation

it18. Assessment and positive feedback

it19. Limited teacher contribution
Genuine questions to which the teacher does not know the answer.

Repeating the learner contribution for all recipients.

Making sure that the teacher has correctly understood the learner's contribution.

Giving feedback to the message rather than the words used.

Rephrasing a learner's contribution

Evaluation of learners' response and using some token (good, ok, yes, well done) to show preference for the answer.

Short teacher's turn which is used for flow of the sequence

The "sharing of understanding" section includes scientific explanations based on the investigation process, learners' claims, and lesson aims. Therefore, teachers elicit the scientific explanation from learners, or they use scientific terms themselves. For this reason, teachers initiate the sequence with questions that work as a stimulus to reveal the scientific knowledge or to form a coherent argument based on the experimental evidence. For example, in Extract 3, the teacher produces an elaboration question that is related to the research findings in line 62: "According to your findings, how did sound that is obtained from objects happen?" as an FPP of the sequence. Following the question, learners raise their hands to be the next speaker in line 67. However, the teacher nominates Ebru who did not raise her hand, so Ebru starts her own turn with "Pardon me? Teacher". After a long silence, Ebru constructs a TCU that is the abstraction of how they got a sound from the rope.

Extract 3: Mrval 1s3, the teacher elicits the answers to the sound and the characteristics of the sound, taking into account the scientific language [01:34.3$02: 24.7]$ 
yap tığımız etkinliğin sonucuna göre(0.7) $\uparrow \dot{B I R}$ (0.7) according to your findings, how did sound that is obtained from objects happen?

Tchr:

+readings from worksheet

$(1.3)$

evet $\uparrow$

yes $\uparrow$

Tchr :

(0.8) ((students raise their hand))

Ebru

Ebru : $\quad{ }^{\circ}>$ efendim hocam $<^{\circ}$

${ }^{\circ}>$ pardon me? teacher $<^{\circ}$

Tchr :

ci simlerden çıkan sesler nasıl meydana geldi how did sound that is obtained from objects happen $\uparrow$

Ebru :

(1.7)

hocam elimizi ıslattık ve iplere sürdügümüzde ei:: we wet our hands and when we touched the rope erm:

Mert :

Tchr:

Mert :

$(0.6)$

happen

$(1.3)$

i:: : kar-

erm: : :

$(1.9)$

$\uparrow$ diyor ki cisimlerden elde edilen sesler nasıl meydana $\uparrow$ it says that how did sound that is obtained from objects

geldi evet $\uparrow$ happen yes $\uparrow$

(0.2) +pointing to Mert

'titreşti çektiği[mizde] ${ }^{\circ}$

it vibrates when we pull it

$[e::]$

\section{waveform}

89 Tchr :

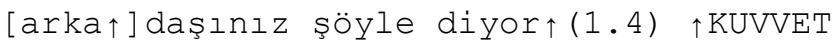
your friends say that (1.4) items vibrated

$91 \quad(1.6)$

92 Veli : $\quad{ }^{\circ}$ doğru ${ }^{\circ}=$ ${ }^{\circ}$ right ${ }^{\circ}=$

93 Tchr : =doğru mu $\uparrow$ 
=is it right $\uparrow$

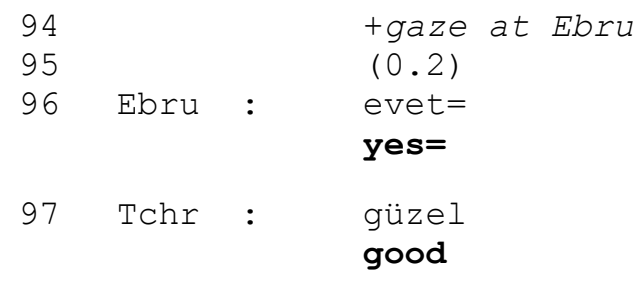

$98 \quad(0.3)$

The answer is dispreferred as the teacher reformulates her question (What do we say for it in general? How did it happen?) to reach the correct answer (line 76). However, Ebru does not give any meaningful answers and uses a hesitation marker in turninitial position (ei::) in line 78. This line is an indicator of a claim of insufficient knowledge (Sert, 2011), but the teacher gives Ebru enough time to produce a TCU. Following 1.9 seconds, the teacher repeats the main question (FFP), and the learners raise their hands to take the floor. The teacher allocates the turn to Mert, who bids for the turn by raising her hand in turn final position (line 82-83). Then Mert responds to the question by drawing on some scientific terms such as "vibration" (line 84) and "waveform" (line 87). While Mert closes down to the possible TRPs, the teacher overlaps and paraphrases the learner contribution (Your friends say that when we applied force, the object vibrates) in lines 88-89. At the end of the sequence, the teacher gazes at Ebru and composes a TCU which entails checking for confirmation about the paraphrased utterance (lines 92-93). The extract is closed with sequence-closing thirds that are also positive assessment tokens, and with silence after the evaluation in lines 96 and 97. In this example, the teacher chooses favorable scientific terms for the question and the context. Thus, using scientific language is crucial for the teachers. Besides, not only the use of the scientific terms, but also their correction, is preferred.

Teachers' pedagogical aims are centered upon findings and the scientific background both to the conclusions and the learners' claims in the "sharing of understanding" lesson phase (Table 3). Therefore, in most cases, the teacher asks questions to elicit responses with their findings (e.g., Extract 3 ) and to find out about arguments concerning the learners' claims. Furthermore, the use of scientific language creates core pedagogical aims which are different from the other lesson phases (e.g., Extract 3). The teacher also seeks appropriate scientific explanations. For this reason, the teacher draws on content feedback, which is a valuable interactional tool for the lesson phase. In addition to that, the teacher checks for comprehension of the scientific subject and peers' explanations as to the last point for the learning and co-construction process.

In Extract 3, which comes from the "sound cup" activity, the teacher's pedagogical aims are to elicit responses about the findings (line 62-75) and to encourage the use of scientific language (line 76-95). The teacher draws on some questions during the lesson phase (line 62-63, 76). The sequence opening consists of a question (how did sound that is obtained from objects happen?). The teacher also refers to the learners' research findings in the first position of the TCU (According to your findings).

Following the opening, the learners raise their hands to be the next speaker. However, the teacher nominates Ebru who did not raise a hand, Ebru explains the experimental process, but the teacher does not accept her answer as correct. Therefore, the teacher reformulates the central question to elicit a scientific explanation rather than a description of the research process (line 76). Thus, the teacher's pedagogical aim changes depending on Ebru's response. The new educational goal is to ensure the use of scientific language related to the subject. This goal is also seen in lines 89 and 90 , during which the teacher selects the best explanation concerning the scientific terminology used in the formation of the response. At the end of the sequence, the teacher gazes at Ebru, and checks for understanding (line 93). When Ebru makes a confirmation in response to the teacher's check, the teacher uses explicit positive assessments (Fagan, 2014).

This phase has a different characteristic from the other lesson phases which have been illustrated in pedagogical aims and interactional patterns (see Table 3). In the present corpus, some "sharing of understanding" tasks include student-student interactions more than teacher-student interaction. This turns the co-construction into a process which is "the joint creation of a form, interpretation, stance, action, activity, identity, institution, skill, ideology, emotion or other culturally meaningful reality" (Jacoby \& Ochs, 1995), which emerges between the students who are K (+) more knowledgeable and K (-) less knowledgeable within the epistemic gradient (Heritage, 2012). On the other hand, in some cases, teacher-student interaction dominates the whole sequence section. Thus, teacher initiation has a role in opening, facilitating the learner contribution, and managing the turn. The situation shows differences from the other parts of the science lesson, and it can be seen in and through the co-construction process.

\section{Discussion}

The lesson phases of an IBS lesson are investigated with regard to interactional patterns, pedagogical aims and interactional tools which are used to perform learning objectives. Before each lesson, teachers define the lesson's aims that are stated explicitly in their lesson plans, or they reflect these goals implicitly throughout the lesson. Even though every classroom has its own sociocultural structure and poses an unpredictable development (Phillips \& Soltis, 2004), these lesson plans provide a scripted structure against the nature of the classrooms. The classroom structures also underscore the notion of the context (Seedhouse, 2004; Walsh, 2006; 2011), which is a construct that can be renewed (context-renewing) based on interactions and that can shape the interaction 
(context-shaped) (Heritage, 2012). As stated earlier, classroom interaction is evaluated regarding the context and all pertaining claims. Therefore, the pedagogical aims show how science teachers carry out an IBL activity, and which points are followed by the teacher. These pedagogical aims have shed light upon the interactional unfolding of the IBL approach through classroom practices explored based on CA. Furthermore, the pedagogical goals require some interactional tools such as the teachers asking knownanswer questions to check for and display learner knowledge, or teachers making embodied corrections or other-initiated selfrepairs to increase learner contributions. Thus, the interactional features help the teachers to work as mediators to reach their pedagogical aims (Seedhouse, 2004).

Drawing upon the findings, the question-answer adjacency pair is the primary sequence organisation in all lesson phases, as in traditional teacher-fronted classroom discourse. However, the question-answer sequences are not similar in all the lesson phases. In the "initiating of the inquiry" lesson phase, the teachers produce a question as a first pair part, and the learners respond to the question as the second part of the adjacency pair, according to the 'interactional asymmetry' (Drew \& Heritage, 1992) of their roles. The question-answer process is oriented to highlighting pedagogical goals and also reveals the students' 'epistemic domain' (Stivers \& Rossano, 2010) or 'epistemic status' (Heritage, 2012) before the investigation process. Epistemic status is distinct from the epistemic stance in that it is encoded moment by moment in turns-at-talk (Heritage, 2012). Thus, the teachers can reveal the learners' epistemic domain by initiating known-answer question sequences also as epistemic search sequences (Sert, 2013). Furthermore, the absence of explicit positive feedback and just paraphrasing learners' explanations instead facilitates successful elicitation of nearly all students' epistemic domains.

On the other hand, the "focusing on the investigation" section comprises both question-answer adjacency pairs and inverted IRF (Jacknick, 2011), which means that the learners construct the question and the teachers give the response. In the last lesson phase, "sharing of understanding", questions initiate the 'dissenting turn' (Hüttner, 2014) between the learners, and the questionanswer adjacency pair is expanded as a demonstration of learners' agency (Waring, 2011). To this end, the change in the organisation of the sequence can explain the structures of the lesson phases, the teachers' pedagogical aims, and emergent discourse patterns between the teacher and the students. For instance, the "beginning of the inquiry" lesson phase structure includes preparations for the investigation, and the teachers ask a question to elicit a response related to background knowledge. In contrast, in the "focusing on the investigation" section, the learners ask a question to maintain their investigations. Furthermore, in the "sharing of the understanding" section, all learners reveal their results and inferences about their work, and the teachers' questions lay the groundwork for discussion if there are different inferences among the students. Walsh (2006) explains this with a different structure of micro context. For example, the materials mode requires talk on the material, so the teacher asks a question, and the learners give short answers. The teacher's questions pave the way for the learners to construct the first pair part in the classroom context mode. Thus, the structure of the micro context leads to diversification of the sequence organisation.

The lesson phases also have a distinct difference in terms of turn-taking and turn allocation. Turn allocation emerges based on a learner-bidding and teacher-allocating structure in the "initiating the inquiry" section. In the "sharing of the understanding" section, turn allocation arises as learner-bidding and teacher-allocating when the teachers ask a question related to the findings. The learner-bidding and teacher-allocating turn-taking structure also unpacks 'epistemic stance' (Heritage, 2012) and 'embodied allocation' (Kääntä, 2010). The learners raise their hands to show their epistemic stance as a K (+) more knowledgeable, and the teachers select one of them by calling out the candidate speaker's name and pointing to her/him as well. Thus, the teachers' questions act as an epistemic search sequence (Jakonen \& Morton, 2015; Sert, 2013) and learners' bidding acts an 'epistemic stance' that is encoded moment by moment in turns-at-talk (Heritage, 2012). Besides that, teachers' participation as a group member or an expert peer is the most exciting part of the turn-taking in all lesson phases, particularly in that the interactional asymmetry of roles disappears in the "focus on investigation" section. It also shows that the teacher gives space for learning (Walsh \& Li, 2013) during this lesson phase by staying one step behind.

As stated before, the "focus on the investigation" lesson phase consists of student-student interactions rather than teacherstudent interactions. With this in mind, the teachers' pedagogical aims are explicated in and through their role as an observer and as an expert fellow in the research group. The teachers' educational foci lie at the heart of checking the investigation process and ensuring the learners' trouble-free research engagements. Due to the teachers' strategies (teachers' turn allocation methods, and teacher-student interactions), learner contributions remain minimal, which further underscores reliance on teacher turns, thus decreased student participation even though the teachers draw on attention-getter devices, particularly 'imperatives with high volume' (Pekarek-Doehler \& Pochon Berger, 2015) to boost interaction with students. The sequential structure and the teachers' educational goals lead to the emergence of these interactional tools. According to Seedhouse (2004), if the teacher's pedagogical aim changes in micro-moments of lesson time, it causes changes in talk-in-interaction.

The last lesson phase and the last part of the lesson is also to some extent the most crucial episode regarding 'doing learning' (Sahlström, 2011) and 'talking science' (Lemke, 1990; Moje, 1995) based on the evidence-based scientific debate (Author, 2016). Furthermore, this lesson phase is also valuable due to the emergence of the co-construction process in and through studentstudent discussions with the use of coherent arguments, engagement in experimental data, orientation to evidence and their background scientific knowledge. For that reason, the teachers' pedagogical aims are gathered around creating a learning space for the students, encouraging more than one student's participation in scientific discussions, ensuring the use of scientific language, and eliciting arguments concerning the learners' claims for whole group understanding. These pedagogical aims limit 
the teachers' contributions through limited content feedback for the students and limited assessment of the students' contributions. The change in the interactures depending on the pedagogical goals shows the intricate relationship between the pedagogy and the role of interaction (Seedhouse, 2004).

The last important point for this section is to show preference and dispreference organisations in the lesson phases. At the outset of an IBS lesson, which is the "initiating of inquiry" lesson phase, the teachers do not use strongly dispreferred utterances and draw on a preference organisation for shaping learner contributions. They manage the preference organisation by showing alignment with a mitigated answer, which keeps learners' participation alive. Besides that, the teachers draw on turn-initial address terms (Schegloff, 2007) to select the next speaker without explicitly highlighting any dispreference. Pomerantz (1987) notes that using dispreferred utterances is not preferred in social interaction due to the adverse effects on the flow of the conversation. Goffman (1967) also states that openly expressing disagreement leads to face-threatening effects, which causes further adverse effects on participation in a given social community. The interactional pattern which frequently occurs throughout the "initiating of the inquiry" section is as follows: the teachers' questions about students' background knowledge or previous lessons initiates a sequence. The responses elicited from more than one student are usually relevant to the teachers' questions. Finally, the teachers avoid any evaluation of students' contributions. The nature of IBS teaching and scientific investigation reflects a requirement for discussions and forming coherent arguments related to results (Crawford, 2007).

\section{Conclusion}

In line with the research questions, two different science classrooms were investigated by employing CA to unpack the interactional structure of IBSE classrooms. The inquiry lessons were firstly defined as 'lesson phases' concerning their interactional differences. Secondly, teachers' pedagogical aims and interactional tools (interactures) were described in all these different phases.

The first research question was "How is teacher-student interaction sequentially organised in IBS classrooms?". As a result of the micro-detailed analysis of the classroom data, it was seen that the lesson was demonstrably divided into various parts. At first, the lesson parts were clearly identified as the pre-inquiry task, implementation of the task, and post-inquiry task. Furthermore, the teachers' and the students' interactions also differed in these lesson parts, such as whole-class discussions in the pre-inquiry task; group research in some experiments oriented to the implementation process; and finally, again whole-class presentations and discussions based on the findings. Due to the various actions occurring throughout the lesson, all sequential organisations between the teacher and students brought about some changes. In line with the micro-analysis and relevant conclusions, an IBS lesson flow was identified in three distinct lesson phases: initiating the inquiry, focusing on the investigation and sharing of understanding.

The present research draws on some inquiry-based tasks that have pre-identified learning aims written in the lesson plan before the lesson. Thus, the lesson plan comprises the entire teaching sequence, and it also targets some goals which are desired points to be enacted at the end of the lessons or activities (Mortimer \& Scott, 2003; Seedhouse, 2004). Besides that, the teachers draw on some pedagogical focus/aims/goals to reach the highest level of learning objectives. Learning the purpose of a science lesson has a static structure. However, pedagogical objectives can change depending on the classroom context. 'Interactional tools' were adopted as a term with reference to the 'interactures', to uncover the relationship between the lesson phase and relevant interactional tools.

\section{Implications}

The present study includes real classroom data and their in-depth analyses in line with a micro-analytic approach, to unpack interactional unfolding of the IBS classrooms. At the end of the analysis process, various lesson micro-contexts are identified based on the teachers' and students' roles and a great variety of interactional resources. Furthermore, interactional fingerprints are discussed under the lesson phase types, teacher's pedagogical aims, and interactional tools to reach a clear understanding of the IBS lesson flow. These pedagogical objectives and relevant interactional tools can provide effective interactional instances when teachers carry out investigation-based science lessons. Teachers should evaluate their classroom interactions in line with the analyses of the emergent micro interactional cases and check for appropriate pedagogical aims and interactional tools. For instance, if a teacher aims to increase learner contributions in the "initiating of the inquiry" lesson phase, he or she should not give feedback to every student turn.

The pedagogical foci and the interactional features demonstrate the interactional mechanisms of an IBS lesson for all stakeholders, including the teachers, teacher educators and researchers. It also supports teachers' awareness of classroom interactional competence (CIC) concerning both horizontal (interactional features) and vertical discourse (basically pedagogical focus or systematically part of the lesson) that generate "language which relates the internal structure of specialized knowledge, the positional nature of their fields or areas of practice, identity constructions and their change, and the forms of acquisition for successful performances" (Bernstein, 1999; p. 157). The last suggestion is oriented to continuing professional development (CPD) programme that can be designed by adopting the framework discussed in this paper to increase the 'interactional awareness' (Walsh, 2011) of teachers. Later on, the development of teachers' interactional competencies and their skills can be investigated to evaluate the quality of the contextual framework of this study. 


\section{Declaration of Conflicting Interests}

The author(s) declared no potential conflicts of interest with respect to the research, authorship, and/or publication of this article.

\section{Acknowledgement}

We would like to thank Dr Olcay Sert for his support as the second thesis advisor and for his role in the emergence of this study.

\section{Funding}

The author(s) received no financial support for the research, author-ship, and/or publication of this article.

\section{Statements of publication ethics}

We hereby declare that the study has no unethical issues and that research and publication ethics have been observed carefully.

\section{Author contribution statements}

This paper was prepared from the first author's PhD thesis under supervision by the second author.

\section{Ethics Committee Approval Information}

This paper was prepared from the first author's PhD thesis and the thesis has ethical approval.

\section{REFERENCES}

Abd-El-Khalick, F., Boujaoude S., Duschl, R., Lederman, G. N., Mamlok-Naaman, R., Niaz, M., Treagust, D., et. al. (2004). Inquiry in science education: International perspectives. Science Education, 88(3), 397-419. https://doi.org/10.1002/sce.10118

Abrahams, l., \& Millar, R. (2008). Does practical work really work? A study of the effectiveness of practical work as a teaching and learning method in school science. International Journal of Science Education, 30(14), 1945-1969. https://doi.org/10.1080/09500690701749305.

Bernstein, B. (1999). Vertical and horizontal discourse: an essay. British Journal of Sociology of Education, 20(2), 157-173. https://doi.org/10.1080/01425699995380.

Brandt, A. (2011). The maintenance of mutual understanding in online second language talk [Unpublished Doctoral Dissertation]. Newcastle University.

Breen, M. (1989). 'The evaluation cycle for language learning'. In R. K. Johnson (ed.). The second language curriculum. Cambridge University Press.

Crawford, A. B. (2007). Learning to teach science as inquiry in the rough and tumble of practice. Journal of Research in Science Teaching, 44(4), 613-642. https://doi.org/10.1002/tea.20157.

Darling-Hammond, L., Flook L., Cook-Harvey, C., Barron, B., \& Osher, D. (2020). Implications for educational practice of the science of learning and development. Applied Developmental Science, 24(2), 97-140. https://doi.org/10.1080/10888691.2018.1537791.

Drew, P., \& Heritage, J. (1992). Analyzing talk at work: An interaction. In P. Drew and J. Heritage (Eds.), Talk at work: Interaction in institutional settings (pp. 3-65). CUP.

Duschl, R. A., \& Osborne, J. (2002). Supporting and promoting argumentation discourse in science education. Studies in Science Education, 38(1), 39-72. https://doi.org/10.1080/03057260208560187

Edwards, D., \& Mercer, N. (1987). Common knowledge: The development of understanding in the classroom. Routledge.

Erickson, F. (2004). Talk and social theory: Ecologies of speaking and listening in everyday life. Polity Press.

Evnitskaya, N. (2012). Talking science in a second language: The interactional co-construction of dialogic explanations in the CLIL science classroom [Unpublished Doctoral Dissertation]. Universitat Autònoma de Barcelona

Evnitskaya, N., \& Morton, T. (2011). Knowledge construction, meaning-making and interaction in CLIL science classroom communities of practice. Language and Education, 25(2), 109-127.

Fagan, D. S. (2014). Beyond "excellent": uncovering the systematicity behind positive feedback turn construction in ESL classrooms. NovitasROYAL (Research on Youth and Language), 8(1), 45-63.

Finlayson, O., McLoughlin, E., Coyle, E., McCabe, D., Lovatt, J., \& van-Kampen, P. (2015). SAILS inquiry and assessment units. Dublin

Garfinkel, H. (1964). Studies of the routine grounds of everyday activities. Social Problems, 11(3), 225-250. https://doi.org/10.2307/798722

Goffman, E. (1983). The interaction order. American Sociological Review, 48(1) 1-17. https://doi.org/10.2307/2095141

Heath, C., Hindmarsh, J., \& Luff, P. (2010). Video in qualitative research: Analysing social interaction in everyday life. Sage.

Heritage, J. (1997). Conversational analysis and institutional talk: analyzing data. In D. Silverman (Ed.), Qualitative research: Theory, method and practice. Sage Publications.

Heritage, J. (2012). Epistemics in action: Action formation and territories of knowledge. Research on Language and Social Interaction, 45(1), 125. https://doi.org/10.1080/08351813.2012.646684 
Hüttner, J. (2014). Agreeing to disagree: 'doing disagreement' in assessed oral L2 interactions. Classroom Discourse, 5(2), $194-215$. https://doi.org/10.1080/19463014.2014.893897

Jacknick, C. M. (2011). "But this is writing”: post-expansion in student-initiated sequences. Novitas-ROYAL (Research on Youth and Language), $5(1), 39-54$.

Jacoby, S., \& Ochs, E. (1995). Co-construction: An introduction. Research on Language and Social Interaction, 28(3), 171-183. https://doi.org/10.1207/s15327973rlsi2803_1

Jakonen, T., \& Morton, T. (2015). Epistemic search sequences in peer interaction in a content-based language classroom. Applied Linguistics, 36(1), 73-94. https://doi.org/10.1093/applin/amt031

Jenks, C. J. (2011). Transcribing talk and interaction: Issues in the representation of communication data. John Benjamins.

Jin, H., Wei, X., Duan, P., Guo, Y., \& Wang, W. (2016). Promoting cognitive and social aspects of inquiry through classroom discourse. International Journal of Science Education, 38(2), 319-343. https://doi.org/10.1080/09500693.2016.1154998

Kääntä, L. (2010). Teacher turn-allocation and repair practices in classroom interaction: A multisemiotic perspective [Doctoral dissertation]. University of Jyväskylä

Kaya, G. (2017). Teacher talk and learner contributions in inquiry based science education: A conversation analytic examination [Unpublished Doctoral Dissertation]. Hacettepe University

Kaya, G., \& Yılmaz, S. (2016). The impact of open inquiry based learning on students' achievement and development of science process skills $H$. U. Journal of Education, 31(2), 300-318. https://doi.org/10.16986/HUJE. 2016016811.

Kaya, G., Şardağ, M., Cakmakci, G., Doğan, N., İrez, S., \& Yalaki, Y. (2016). Discourse patterns and communicative approaches for teaching nature of science. Education and Science, 41(185), 83-99. https://doi.org/10.15390/EB.2016.4852.

Kelly, G. (2014). Discourse practices in science learning and teaching. In N. G. Lederman \& S. K. Abell (Eds.), Handbook of Research on Science Education. Routledge

Kelly, G. J. (2007). Discourse in science classrooms. In S. K. Abell, \& Lederman, N, G. (Ed.), Handbook of research on science education (pp. 443469). Lawrence Erlbaum Associates.

Kelly, G. J., \& Chen, C. (1999). The sound of music: Constructing science as sociocultural practices through oral and written discourse. Journal of Research in Science Teaching, 36(8), 883-915. https://doi.org/10.1002/(SICI)1098-2736(199910)36:8<883::AID-TEA1>3.0.CO;2-I

Kelly, G. J., \& Crawford, T. (1996). Students' interaction with computer representations: Analysis of discourse in laboratory groups. Journal of Research in Science Teaching, 33(7), 693-707.

Koole, T. (2010). Displays of epistemic access: Student responses to teacher explanations. Research on Language \& Social Interaction, 43(2), 183209. https://doi.org/10.1080/08351811003737846

Labov, W. (1970). The study of language in its social context. Springer.

Leach, J., \& Scott, P. (2002). Designing and evaluating science teaching sequences: an approach drawing upon the concept of learning demand and a social constructivist perspective on learning. Studies in Science Education, 38(1), 115-142. https://doi.org/10.1080/03057260208560189.

Lemke, J. L. (1990). Talking science: Language, learning, and values. Ablex Lessons.

Lemke, J. L. (2001). Articulating communities: Sociocultural perspectives on science education. Journal Research Science Teaching, 38(3), 296316. https://doi.org/10.1002/1098-2736(200103)38:3<296::AID-TEA1007>3.0.CO;2-R

Liddicoat, A. J. (2007). An introduction to Conversation Analysis. Continuum.

Markee, N. (2000). Conversation Analysis. Routledge.

McHoul, A. (1978). The organization of turns at formal talk in the classroom. Language in Society, 7(2), $183-213$. https://doi.org/10.1017/S0047404500005522

Mehan, H. (1979). Learning lessons: Social organization in the classroom. Harvard University Press.

Mercer, N., Dawes, L., Wegerif, R., \& Sams, C. (2004). Reasoning as a scientist: Ways of helping children to use language to learn science. British Educational Research Journal, 30(3), 359-377. https://doi.org/10.1080/01411920410001689689

Millar, R., \& Osborne, J. (1999). Beyond 2000. King's College.

Minner, D. D., Levy, J. A., \& Century, J. (2010). Inquiry-based science instruction-what is it and does it matter? results from a research synthesis years 1984 to 2002. Journal of Research In Science Teaching, 47(4), 474-496. https://doi.org/10.1002/tea.20347

Moje, E. B. (1995). Talking about science: an interpretation of the effects of teacher talk in a high school science classroom. Journal of Research in Science Teaching, 32(4), 349-371. https://doi.org/10.1002/tea.3660320405

Mortensen, K. (2008). Selecting next-speaker in the second language classroom: How to find a willing next-speaker in planned activities. Journal of Applied Linguistics, 5(1), 55-79. https://doi.org/10.1558/japl.v5i1.55

Mortensen, K. (2009). Establishing recipiency in pre-beginning position in the second language classroom. Discourse Processes, 46(5), 491-515. https://doi.org/10.1080/01638530902959463

Mortensen, K., \& Hazel, S. (2011). Initiating round robins in the L2 classroom - preliminary observations. Novitas-ROYAL (Research on Youth and Language), 5(1), 55-70.

Mortimer, E. F., \& Scott, P. H. (2000). Analysing discourse in the science classroom. In J. Leach, R. Millar \& J. Osborne (Eds.), Improving science education: The contribution of research. Open University Press.

Mortimer, E. F., \& Scott, P. H. (2003). Meaning making in secondary science classrooms. Open University Press. 
NGSS Lead States. (2013). Next generation science standards: For states, by states. The National Academy Press.

NRC. (1996). National science education standards. National Academy Press.

NRC. (2000). Inquiry and the national science education standards. National Academy Press.

Oliveira, A. W. (2010). Developing elementary teachers' understanding of the discourse structure of inquiry-based science classrooms. International Journal of Science and Mathematics Education, 8(2), 247-269. https://doi.org/10.1007/s10972-009-9157-4

Pedaste, M., Mäeots, M., Siiman, L. A., de Jong, T., van Riesen, S. A., Kamp, E. T., ... et al. (2015). Phases of inquiry-based learning: Definitions and the inquiry cycle. Educational Research Review, 14, 47-61. https://doi.org/10.1016/j.edurev.2015.02.003

Pekarek-Doehler, S., \& Pochon-Berger, E. (2015). The development of L2 interactional competence: evidence from turn-taking organization, sequence organization, repair organization and preference organization. In Teresa Cadierno, \& Soren W. Eskildsen (Eds.), Usage-Based perspectives on second language learning (pp. 233-270). De Gruyter Mouton.

Philips, D. C. \& Soltis, J. F. (2004). Learning: Perspectives. Nobel Publishing

Pomerantz, A. (1987). Descriptions in legal settings. In G. Button \& J. R. E. Lee (Eds.), Talk and social organization (pp. 226-243). Multilingual Matters Ltd.

Psathas, G. (1995) Conversation Analysis. Sage.

Rocard, M., Csermely, P., Jorde, D., Lenzen, D., Walberg-Henriksson, H., \& Hemmo, V. (2007). Science Education now: A renewed pedagogy for the future of Europe. European Commission.

Roth, W. -M., Ritchie, S. M., Hudson, P., \& Mergard, V. (2011). A study of laughter in science lessons. Journal of Research in Science Teaching, 48, 437-458. https://doi.org/10.1002/tea.20412

Ryder, J., \& Leach, J. (2008). Teaching about the epistemology of science in upper secondary schools: an analysis of teachers' classroom talk. Science \& Education, 17(2), 289-315. https://doi.org/ 10.1007/s11191-006-9007-0

Rymes, B. (2008). Classroom discourse analysis: A tool for critical reflection. Hampton Press.

Sacks, H. (1992). Lectures on conversation. Blackwell

Sahlström, F. (2011). Learning as social action. In J. K. Hall, J. Hellermann, \& S. P. Doehler (Eds.), L2 Interactional Competence and Development (pp. 45-65). Multilingual matters.

Schegloff, E. A. (2007). Sequence organization in interaction: A primer in conversation analysis. Cambridge University Press.

Schwab, G. (2011). From dialogue to multilogue: a different view on participation in the English foreign-language classroom. Classroom Discourse, 2(1), 3-19. https://doi.org/10.1080/19463014.2011.562654.

Scott, P. (1997). Developing science concepts in secondary classrooms: an analysis of pedagogical interactions from a Vygotskian perspective [Doctoral dissertation]. University of Leeds

Seedhouse, P. (2004). The interactional architecture of the language classroom: A conversation analysis perspective. Blackwell.

Sert, O. (2013). 'Epistemic Status Check' as an interactional phenomenon in instructed learning settings. Journal of Pragmatics, 45(1), 13-28. https://doi.org/10.1016/j.pragma.2012.10.005

Sert, O. (2015). Social interaction and L2 classroom discourse. Edinburgh University Press.

Sert, O., \& Seedhouse, P. (2011). Introduction: Conversation analysis in applied linguistics. Novitas-ROYAL (Research on Youth and Language), 5(1), 1-14.

Sert, O., \& Walsh, S. (2012). The interactional management of claims of insufficient knowledge in English language classrooms. Language and Education, 27(6), 1-24,

Sidnell, J. (2010). Conversation Analysis an introduction. WileyBlackwell.

Sinclair, J., \& Coulthard, M. (1975). Towards an analysis of discourse. Oxford University Press.

Tang, K. S. (2016). The interplay of representations and patterns of classroom discourse in science teaching sequences. International Journal of Science Education, 38(13), 2069-2095.

ten Have, P. (2007). Doing Conversation Analysis. Sage.

Urmeneta, E. C. (2008). Talking English to learn science. A CLIL experience in Barcelona. In M. Dooly and D. Eastment (Eds.), 'How we're going about it': Teachers' voices on innovative approaches to teaching and learning languages (pp. 127-138). Cambridge Scholar Press.

van Aalst, J., \& Truong, M. S. (2011). Promoting Knowledge Creation Discourse in an Asian Primary Five Classroom: Results from an inquiry into life cycles. International Journal of Science Education, 33(4), 487-515.

Walsh, S. (2006). Investigating classroom discourse. Routledge.

Walsh, S. (2011). Exploring classroom discourse: Language in action. Routledge.

Walsh, S. \& Li, L. (2013). Conversations as space for learning. International Journal of Applied Linguistics, 23(2), $247-266$. https://doi.org/10.1111/ijal.12005

Waring, H. Z. (2008). Using explicit positive assessment in the language classroom: IRF, feedback, and learning opportunities. The Modern Language Journal, 92(4), 577-594. https://doi.org/10.1111/j.1540-4781.2008.00788.x

Waring, H. Z. (2011). Learner initiatives and learning opportunities in the language classroom. Classroom Discourse, 2(2), $201-218$. https://doi.org/10.1080/19463014.2011.614053

Windschitl, M. (2004). Folk theories of "inquiry:" How preservice teachers reproduce the discourse and practices of an atheoretical scientific method. Journal Research in Science Teaching, 41(5), 481-512. https://doi.org/10.1002/tea.20010 
Windschitl, M., Thompson, J., \& Braaten, M. (2008). How novice science teachers appropriate epistemic discourses around model-based inquiry for use in classrooms. Cognition and Instruction, 26(3), 310-378. https://doi.org/ 10.1080/07370000802177193

Zemel, A. \& Koschmann, T. (2011). Pursuing a question: reinitiating IRE sequences as a method of instruction. Journal of Pragmatics, 43(2), 475488. https://doi.org/10.1016/j.pragma.2010.08.022. 